\title{
Schools for Democracy: A Waste of Time? Roles, Mecha- nisms and Perceptions of Civic Education in Czech and German Contexts ${ }^{1}$
}

\author{
Daniela Prokschová ${ }^{2}$ \\ Institute of Sociology of the Czech Academy of Sciences, Prague
}

\begin{abstract}
Schools for Democracy: A Waste of Time? Roles, Mechanisms and Perceptions of Civic Education in Czech and German Contexts. This article investigates the role of school-based civic education in the formation of political commitment, motivation and selfefficacy. The article is based on 60 qualitative interviews with university students from the Czech Republic and East and West Germany. Results indicate more favourable perceptions and evaluations of civic education by German students and offer practical recommendations for improving Czech education policy. Civic education has a positive impact particularly on children who were already interested in politics before beginning civic education classes. Apart from civic education, teachers, peers, school climate, organisational membership and family background are crucial factors in political engagement and commitment. Sociológia 2020, Vol. 52 (No. 3: 300-320)

https://doi.org/10.31577/sociologia.2020.52.3.13
\end{abstract}

Key words: Civic education; political motivation; school climate; secondary political socialisation; qualitative analysis

\section{Introduction}

'So now we have democracy, it's time to find some democrats.' Tomáš Garrigue Masaryk

The above-cited words of the first Czechoslovakian president Tomáš Garrigue Masaryk pointed to the postulate of political science that no democratic regime can exist without active, responsive and self-confident citizens. In the light of the rapidly decreasing rate of conventional participation (such as voting and membership in traditional political organisations) among young people under 30 years of age (Norris 2002; Verba et al. 1995; Zukin et al. 2006) it is now more relevant than ever to investigate the source of young people's attitudes towards political participation. In order to shed some light on the puzzle of the roots of youth political engagement, the article focuses on the role of civic education in motivating political action and inspiring self-confident citizenship.

A citizen with a sense of self-efficacy believes that he/she is capable of and entitled to influence political process and creates what is termed by Almond and Verba as 'participant culture' (1963) and by Jenkins et al. as (2015)

\footnotetext{
1 The research leading to this article received funding from the project 'Changes in the Perception of the Role of Government after the Crisis. The Czech Republic in Comparative Perspective' (No. 16-04885S) supported by the Czech Science Foundation.

2 Address: Mgr. Daniela Prokschová, Institute of Sociology of the Czech Academy of Sciences, Jilská 1, 11000 Praha 1, Czech Republic. E-mail: daniela.prokschova@soc.cas.cz
} 
'participatory culture'. Such a citizen understands not only the functioning of the political system, but also his/her role in it. He/she reflects critically on the political system and considers the normative dimensions of political life such as the legitimacy of the system and each person's rights and duties (Almond Verba 1963; Jenkins et al. 2015).

The theoretical background of this article lies at the intersection of the social-psychological perspective of participation and political socialisation theory which describes participatory behaviour as a product of the interplay between the participating individual and mobilising structure (Hooghe - Stolle 2005: 43). The development of political interest, opinion and behaviour formation is a product of a wider social context to which young people are exposed. Political socialisation refers to social contacts and connections among family, school, acquaintances, and peer group members as mediators between the individual and societal levels of participation (Hooghe - Stolle 2005; Wood et al. 2018).

In this regard, schooling has multiple impacts on the process of political socialisation including introducing the concept of civic education as well as formal and informal interactions with teachers and peers. Schools provide, as does the family context, an opportunity to negotiate political opinions, discuss individual points of view and form coalitions and compromises. Besides its formal education function, school plays an important role in developing abilities such as social responsibility, cooperation, promoting citizenship competences, democratic values and participation skills (Macháček 2002; Preissová Krejčí et al. 2016).

Civic education programmes introduced to stimulate young people's political interest and promote critical thinking and media literacy are expected to result in higher political participation, self-confident and active citizenship (Manning - Edwards 2014; Quintelier 2013). Another goal of school-based civic education is to mitigate differences in political knowledge among students from families with diverse socioeconomic backgrounds and thus enable more equal participation (Castillo et al. 2015; Kudrnáč 2017; Tonge et al. 2012). Civic education also aims to promote an inclusive classroom climate, with a view to combating stereotypes and preventing extremism and racism (Preissová Krejčí et al. 2016; Kusá - Juščáková 2017).

However, does this work? As stated by Tonge et al., (2012: 586), civic education is occasionally related to the threat of social engineering and ideological indoctrination. Manning and Edwards' (2014) study systematically reviewed the impact of civic education on young people's political participation found only marginal evidence of the influence of civic education programmes on electoral behaviour. However, the study indicated that civic education increases non-electoral participation to a certain extent (for instance 
signing petitions). Nevertheless, there are contradictory findings in this area. For instance, Niemi and Junn (2005) and Tonge et al. (2012) explored the ways in which school-based civic education significantly affects political knowledge and interest.

Nevertheless, Manning and Edwards (2014) who focused only on Englishspeaking countries were aware of this limitation and called for further investigation. The situation in the 'new' democracies of Central and Eastern Europe is more complex and specific ${ }^{3}$. A long experience of communism has left imprints on the value systems of the population of 'new' democracies such as the Czech Republic and East Germany, which are seeing a participation deficit in comparison with traditional Western democracies (Gyárfášová Bútorová 2010).

The communist heritage is still present in citizens' underdeveloped competencies, political alienation and reliance on social networks on one hand and in the paternalistic attitudes stressing the role of the state on the other (Mansfeldová 2013). The traces of the former regime are difficult to eradicate despite the introduction of basic rights and freedoms (Bernhagen - Marsh 2007). This may have negative consequences for civic education policy. In addition, civic education may evoke the political propaganda of the communist regime.

Therefore, this article aims to focus on evaluation of school-based civic education and its role in the individual's path to activism in a Central European context. Specifically, the aim of the article is to answer the question: 'What was the perceived quality, role and impact of civic education at Czech and German schools on students' political engagement?' The article focuses on the evaluation of civic education programmes by former students, and their perceived influence on stimulating political interest, engagement and a sense of self-efficacy.

\section{Civic education policy in the Czech Republic and Germany}

Germany represents a successful implementation of democracy-building via civic education and ranks among the countries with the most developed system of civic education worldwide (Kuhn 2013; Reinhardt 2007). The Czech Republic, on the other hand, is among the 'new' democracies with an underdeveloped and underfunded conception of civic education (Č́p et al. 2013; Protivínský - Dokulilová 2012). During 2007 - 2013, the Czech government allocated 10.9 million EUR to support 77 projects focused on civic

\footnotetext{
${ }^{3}$ For example, international studies such as (Campbell 2008) and (Quintelier and Hooghe 2012) explored how the climate of open discussion in classrooms stimulates political interest and willingness to voting but these results were not proved in the Czech environment (Kudrnáč 2017).
} 
education. In comparison, civic education in Germany received 350 million EUR in 2013 and between 2007 to 2013, approximately 2,380 million EUR in funds was allocated (Kalina et al. 2013) .

Germany's $20^{\text {th }}$ century history clearly demonstrated that the relationship between economic prosperity and democracy is not a given, and a sustainable democratic regime has cultural prerequisites such as public identification with democratic values (Almond - Verba 1963). Civic education was introduced after the Second World War by the Western allies as a tool of denazification, moral re-education and promotion of democratic values among the German population (Ehmann 2004; Kuhn 2013).

The current system of civic education in Germany is very heterogeneous and pluralistic. It is administered by state institutions on federal level as well as by individual federal states. Civic education on federal level is provided by the Federal Agency for Civic Education (Bundeszentrale für politische Bildung BPB), by specialized subjects at school, and by federal ministries (Reinhardt 2007).

Moreover, the civic sector actively participates in this education area through (1) foundations which are ideologically close to political parties represented in the Federal parliament (Bundestag), (2) foundations connected with private companies (e.g. Robert Bosch Foundation), (3) church organisations, (4) trade unions and by (5) institutions for adult education, called Adult Education Centres (Volkshochschulen) (Kalina et al. 2013). After German reunification, the Western concept of civic education was adopted in East German federal states. Nevertheless, German system of civic education also faces certain limits. For instance, it still fails to bridge gender-specific discrepancies in political attitudes (Westle 2006).

Civic education has a long and rich tradition in the Czech Republic. The First Czechoslovak Republic adopted the first law concerning civic education in 1919. In 1922, the so-called 'Small Education Act' introducing courses of civic education to secondary and grammar schools was adopted (Smékal et al. 2010: 17). Currently, in the Czech education system, a specialized subject called 'Civics' (Občanská nauka or Občanská výchova) at primary and secondary schools and 'Introduction to Social Sciences' (Základy společenských věd) at grammar schools are focused on civic education. Nevertheless, the above-mentioned subjects are not afforded sufficient respect in the Czech context ${ }^{5}$. Moreover, in the Czech Republic, frontal teaching is the norm, and the knowledge-based dimension of civic education is emphasised

\footnotetext{
${ }^{4}$ Nevertheless, we should also take into account different sizes of the countries, the number of teachers, and the fact that German civic education is anchored in the constitution as a priority while Czech schools try to be 'apolitical'.

5 This pattern is typical in other countries, for instance, British civic education also has a marginal status in the eyes of exam-focused teachers (Mycock - Tonge 2012).
} 
(e.g. description of the electoral system, number of MPs, dates of important historical events) whereas normative issues (such as political legitimacy, expectations of the political system, citizenship rights and responsibilities) are often neglected (Kalina et al. 2013; Preissová Krejčí et al. 2016; Protivínský Dokulilová 2012).

Similarly, less formalized activities (e.g. project-based learning, discussion groups, government simulation games, excursions to political institutions) do not receive enough space and support in education plans (Č́p et al. 2013). Teachers complain of an over-full curriculum and inappropriate textbooks. The problem is also inadequate education at Faculties of Education (Preissová Krejčí et al. 2016). According to Czech education experts from the civic sector (among others Čáp et al. 2013; Kalina et al. 2013; Protivínský - Dokulilová 2012), civic education at schools does not help students to orient themselves in local and global problems.

A similar pattern is also visible in the other 'new' democracies. For instance, results from Slovakia, with which the Czech Republic shares more than 70 years of common history in their joint existence as Czechoslovakia, indicate a low impact of civic education but point to the formative influence of associational membership (Kusá - Juščáková 2017; Macháček 2002; Zápotočná - Lukšík 2010) ${ }^{6}$.

Slovak experience shows a higher level of patriotism among the young generation than the EU average, while young citizens' associational membership and their sense of self-efficacy and social responsibility are below the EU average (e.g. Macháček 2002; Zápotočná - Lukšík 2010). Moreover, results indicate lukewarm attitudes to inclusion of children with special needs in mainstream schools and the lack of tolerance towards minorities (Kusá Jušćáková 2017). However, students from secondary schools with a special emphasis on cultural inclusion and diversity have generally fewer negative opinions about ethnic minorities. Research also shows a link between the social and cultural capital of a family and their degree of inclusiveness (Kalmárová et al. 2017).

Multicultural education and teaching about ethnic, religious and sexual minorities is considered controversial in civic education in the 'new' democracies (Preissová Krejčí et al. 2016; Lášticová et al. 2018). In this regard, qualitative interviews with teachers show that they are convinced about their relatively low influence on children and would prefer to let controversial issues be discussed in family environments which they consider formative (Kusá -

\footnotetext{
${ }^{6}$ To be more specific, Macháček's (2002) comparison between students from Bratislava and Vienna indicates the relatively detailed political knowledge of Slovak students but their limited organisational membership and citizenship competences in contrast with their Austrian counterparts.
} 
Jušč́ková 2017; Zápotočná - Lukšík 2010). Teachers’ perceptions of their role vary between that of 'moderators' of student discussions, their 'correctors' or impartial 'observers' (Lášticová et al. 2018: 83). However, more enthusiasm and willingness to tackle controversial subjects are visible in the new generation of teachers (Zápotočná - Lukšík 2010).

\section{Methodology}

The presented article draws upon a unique dataset of 60 semi-structured qualitative interviews with university students. Attention is paid mainly to students actively engaged in political or civic organisations: 45 of the interviewed students were organisationally active. An additional 15 interviews with individuals without organisational membership enabled a better understanding of the core group of young people involved in organisations.

The research targets university students who are a specific and relatively select group of young people regarding their political knowledge, skills, expectations, priorities, opportunities and participation. For instance, university students are more likely vote, join political protests, political or civic organisations and hold public office than their peers with lower educational attainment (Dalton 2008; Zukin et al. 2006).

The age limit of the interviewees was set from 18 to 30 years following studies by Bernhagen and Marsh (2007), Gaiser et al. (2010) and Hooghe and Stolle (2005). This life stage of so-called 'provisional adulthood' (Sheehy 2011) is a time when young people's long-term political and professional choices, and social and moral values are formed to a great degree. After leaving university, their political views, values and beliefs remain relatively stable (Gaiser et al. 2010).

Although children and adolescents under 18 years of age have very fresh, recent experience with civic education, they have very limited direct political experience. In contrast, young adults between 18 and 30 years are eligible to vote in public elections, join political organisations and are able to reflect more deeply on their life experiences. Owing to their youth, they have relatively fresher and perhaps more vivid memories than older generations of the process of their secondary socialisation at school, the inception of their interest in politics and factors which motivated them to political action.

Interviews were conducted between 19.6.2014 and 12.4.2016 at universities in the former East Germany (Jena), former West Germany (Mannheim, Cologne) and the Czech Republic (Prague, Ostrava, Olomouc), with 10 interviews conducted in each city. Selected cities are the seats of established universities with a well-developed structure of political and civic organisations providing opportunities for student engagement. Nevertheless, the sampling of cities could not be representative as this would be against the 
logic of qualitative research (Creswell 2013; Rubin - Rubin 2011). Instead, selection was driven by maximizing the degree of variation among different contexts.

In Germany, the selected cities represented an East-West dimension. In the former West Germany, Cologne, the capital of federal state North RhineWestphalia, and Mannheim in the federal state of Baden-Württemberg, were chosen. In the former East Germany, Jena, a high-tech centre and the second largest city of federal state Thuringia, was selected ${ }^{7}$.

In the Czech Republic, economic diversity and university reputation were the criteria for selection. In this regard, the capital city, Prague, the industrial city of Ostrava, and the university city of Olomouc, were selected. Charles University in Prague draws students from across the country due to its tradition and reputation. The city of Olomouc has the highest density of university students in Central Europe while the University of Ostrava has a regional character and impact.

Methodological justifications of the number of interviews and sampling procedures were found in the relevant literature (such as Gerring 2007; Howard 2003; Katrňák 2004; Rubin - Rubin 2011; van Deth 2008). The mix of purposive and convenience sampling was used, therefore, the selection of interviewees could not achieve the criterion of representativeness (Gerring 2007). Nevertheless, the goal was to secure a relatively heterogeneous sample of informants regarding their (1) organisations (type of organisation, ideological profiling on the left- to right-wing spectrum), (2) experiences with politics, (3) sociodemographic and socioeconomic characteristics such as age, gender, field of study and family background. Furthermore, the aim was to reach interviewees from all levels of organisational hierarchy as well as members who are very active, partly active and less active.

Communication partners were selected from 'old' political groups such as parties, youth party organisations and trade unions as well as activists from 'new' types of organised interested groups, for example, ecological, human rights and social justice organisations. Driven by the fact of expanding political opportunities and repertoires of the younger generation (Norris 2002; Verba et al. 1995; Zukin et al. 2006), groups with diverse political allegiance, hierarchical structures and issue-foci were chosen.

The process of approaching interviewees was similar in both countries. A variety of methods was used to recruit participants, including contacting student umbrella organisations, faculty coordinators and lecturers, displaying

\footnotetext{
7 The aim was to avoid regions which are exceptionally characteristically German (such as the federal state Bavaria or the capital city of Berlin) and prefer choosing 'typical' German cities. For instance, according to Jan van Deth, Mannheim is the example of 'average' German city regarding its size, history, political attitudes of citizens, structure of industry and services (van Deth 2008: 13).
} 
posters at universities, informal meetings with students and direct requests to political organisations for participation. The 'snow-ball technique' which works like chain referral when interviewees are asked to recommend other potential interviewees with similar areas of interest was also used.

To reduce the risk of bias, similar conditions for every interview were maintained. The interviews were all conducted by one person (the author) thus ensuring consistency. The length of the interviews was approximately 40-60 minutes. All interviews were recorded and notes were taken. In the Czech Republic, the interviews were conducted in Czech, and in Germany in English. However, the author is satisfied that no significant self-selection bias due to knowledge of English appeared among German communication partners ${ }^{8}$.

Regarding the ethics of the research, all the communication partners were informed in detail about the purposes of interview and signed the informed consent form. All the interviews were anonymized. For the purpose of analysis, interviewed students were assigned pseudonyms. Interviews were verbatim transcribed including stalling words, silences and hesitations.

Applied thematic analysis, the most common method of textual analysis in qualitative research (Guest et al. 2012: 11) was used. This method attends to the identification, analysis and referencing of recurring patterns (themes) in the text. Data coding and analysis was conducted by the author using initial coding and then systematically sorted codes into categories in order to find repeating patterns, connections and mutual relationships.

Firstly, codes within a single interview were developed, followed by analysis of codes across all the interviews to find out what particular concepts meant for groups of interviewees (Rubin - Rubin 2011). Secondly, the codes were constantly compared, re-contextualized and regrouped in order to match them into the bigger analytical units to identify the main themes ${ }^{9}$. The last step was the connection of the themes with sub-themes to create a coherent narrative (Guest et al. 2012; King - Horrocks 2010). For coding and data segmentation, the computer-assisted qualitative software Atlas.ti was used.

The data analysis deals with an interpretative retrospective design which emphasizes life experience and gives space to individual explanations, meanings and understandings. The following limitations stem from its qualitative nature: analysis relies on individual self-reported data and joint reflections and interpretations on the part of the participants as well as those of the researcher (King - Horrocks 2010; Sandberg 2005). It is important to be

\footnotetext{
${ }^{8}$ The most interviewees spoke English fluently. If German communication partners did not know a suitable word or phrase in English, they could say it in German. One informant came with his friend who helped him to translate his answers. On the request of another participant, one interview was conducted in German.

9 The procedure of 'hierarchical coding' to find out if some themes were subsumed within the others was used. The outline for the detailed visualization of the relationship between themes and identification of sub-themes was created, and then all the codes, themes and sub-themes were re-read and their validity in the context of the findings as a whole was assessed.
} 
aware of the fact that these interpretations are influenced by the life experience of the interviewees and their willingness and ability to sufficiently describe their feelings and thoughts (problems with selective memory, exaggeration, attribution and providing socially desirable answers may appear) as well as being influenced by the researcher's analytic skills.

\section{Results}

\section{Civic education between inspiration and pressure}

Analysis of the interviews revealed the notion of 'influence' as a central analytical category in relation to civic education and general school environment. All communication partners described it although this word itself was not always used explicitly. A closer look at the nuanced qualitative data shows that perceptions and evaluations of this category varied according to different contextual characteristics. In other words, the notion of influence had both positive and negative connotations. For instance, it was linked to 'inspiration' or 'pressure' in relation to national, school and family contexts. Figure 1 summarises the most important research findings. The following sources of 'influence' were identified at school: civic education lessons, teachers, school climate ${ }^{10}$ and peer group. Nevertheless, outside of school factors, particularly family influence, were also crucial for the perceived impact of civic education. These sources were often interconnected and appeared in interviews with varying intensity.

Among interviewees, a great diversity in opinions about civic education was presented. On one hand, they described these lessons as 'kind of inspiring', 'very interesting' and 'appealing'. On the other, they perceived them as ' $a$ joke', 'really boring', 'like propaganda' and 'manipulative'. Some Czech and German students articulated the opinion that civic education was too theoretical and disconnected from reality and Czech communication partners criticised the limited time for lessons about politics.

An interesting distinction between the Czech and German interviewees appeared in the perceptions and evaluations of civic education. German interviewees appreciated discussions and interactivity in lessons as seen in the testimony below:

It was very interesting - this was the time of the Fukushima event - how parties reacted to this topic. ... We always discussed party programmes before the elections and I think the teacher was very good, the lessons were very interactive and we watched the news every day to be able to discuss the topics at school (Ingrid, 21, Mannheim, no organisation).

\footnotetext{
${ }^{10}$ Prevailing modes, attitudes and standards in the classroom.
} 
Figure 1: Perceptions and evaluations of school and civic education

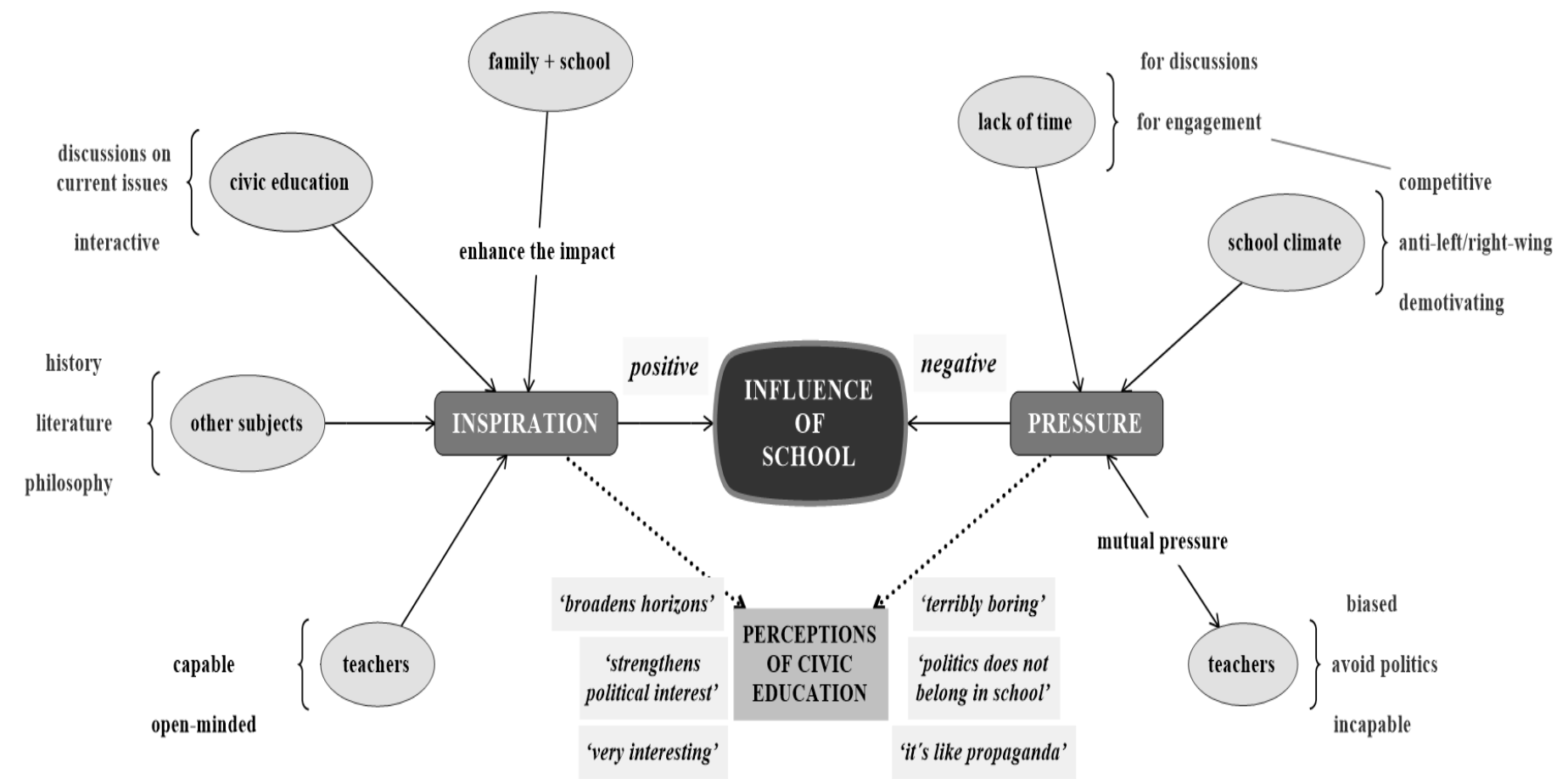

Source: Created by the author 
In this setting of 'power-free discourse', support and respect were valued more than ideological agreement. Czech communication partners on the other hand agreed that their school system primarily focuses on factual information about politics. Nevertheless, this was not prevailingly perceived negatively because 'a person should be interested in it [politics] of their own accord and not be pushed into it by anyone' (Vera, 23, Olomouc, no organisation) and 'they [teachers] are not there [at school] to ideologically indoctrinate us' (Ondřej, 20, Prague, centre-left party, activist). This was the typical line of argumentation in the narratives of the Czech interviewees who were politically non-interested and non-active in any organisation and surprisingly also in the case of some organisational members.

The Czech interviewees mostly considered civic education to be boring and ineffective in terms of stimulating their interest in politics. Moreover, they often associated this education with an inevitable degree of pressure, manipulation and propaganda as noted by a 22 -year-old bachelor student of social sciences from Palacky University in Olomouc:

This [civic education] can become just this propaganda exercise and have a really strong influence [on students]. Discussions [on politics at school] could possibly happen but I don't think that any particular opinion should be promoted in any particular way... I think that it is very complicated considering how many teachers we have and how easy it is [to promote a particular opinion]... it would be easier to ban it [discussions] completely (Arnošt, 22, Olomouc, no organisation).

\section{Teachers as necessary agents of civic education}

An explanation of these reluctant attitudes towards civic education may lie in the distrust in teachers because their influence was perceived as crucial by interviewees in both countries. In this regard, five broad categories emerged as important in the evaluation of the teacher's performance. The typical pattern in Czech narratives labelled teachers as 'incapable', 'biased', and 'apolitical'. The Czech participants pointed to the low qualification of civic education teachers who were certified to teach 'Physical Training combined with Introduction to Social Sciences'. They were not convinced about the level of knowledge or capabilities of their teachers to moderate discussions and promote critical thinking.

In contrast, German communication partners mostly considered their civic education teachers 'neutral', 'inspiring' and 'capable'. They did not doubt their qualification and competences. Erica, a liberal-oriented student from Jena described the role of her civic education teacher in the process of her political identification: 
We had very good teacher, we discussed politics a lot and at the age of 13 or 14 I realized that I liked one position more than the others so I started to take part in politics through JuLis [Young Liberals] and after that in LHG [Liberal University Group] (Erica, 23, Jena, centre-right young organisation).

For Czech and German participants, being a good teacher meant being politically neutral. Nevertheless, the perception of 'neutrality' significantly differed. In the Czech context, it often was a strategy of 'being apolitical' in a sense to avoid politics (especially class discussions on controversial topics such as gender issues or problems concerning ethnic and religious minorities).

On the contrary, German communication partners understood 'neutrality' as an attempt by their teachers to refrain from pushing particular ideological viewpoints during their lessons while not avoiding discussions on controversial issues. In addition, teachers afforded civic education great importance and felt obliged to inform pupils not only about factual information but to lead them towards critical thinking and active citizenship. This approach is illustrated in a statement by Ingrid, a trainee of the Regional Centre for Political Education (Landeszentralle für politische Bildung) in Heidelberg who is considering a teaching career. She sees the biggest advantage of civic education lessons not only in informing students about politics but also in engaging them.

I think it is very important that people know something about politics, the importance of the structures and how the students can influence political process <speaking enthusiastically>. I am not interested in manipulating them but just informing them about politics and what is going on there (Ingrid, 21, Mannheim, no organisation).

Furthermore, participants' political interest was shaped not only by civic education teachers but also by history, language or literature teachers. In this regard, an interesting distinction appeared between the right-wing on one hand and left-wing and environmentally-oriented students on the other. The former wanted to better understand historical events and their consequences. The latter focused more on philosophical or ethical questions such as issues of justice, legitimacy and freedom as the following excerpt demonstrates:

At grammar school, I became interested in philosophy. I read different books about philosophy and I had a teacher who got me really interested in ethical questions - I mean exploring how things are and how they should be... you know, the difference between legality and legitimacy (Eva, 30, Prague, ecological activist).

Right-wing and conservative students mentioned ancient history (such as the beginning of Greek democracy) but also recent historical events, for example, the German experience with National Socialism and the Czech 
communist legacy. It should be mentioned that the interest of interviewees in the issue of National Socialism was worrying for some parents. Nevertheless, German communication partners felt no concerns when discussing issues connected with Nazism at school. Czech interviewees on the other hand, as well as some participants from the former East Germany, noticed their teachers' efforts to avoid discussions on communism. This behaviour represents a 'discourse of avoidance' where controversial issues are omitted from discussions.

In order to shed some light on the reasons for this reluctance, we show the dilemma felt by history teachers as experienced by Ondřej, a student of pedagogy. He claims that historical explanations usually end with the Second World War because the events that followed are still uncomfortably vivid in the collective memory.

Since 1989, there has been this feeling in the population that all the people were dissidents < smiling ironically as he pronounces the word 'dissidents'>. And you never know if you teach the kid of a communist prisoner or someone from a communist family. On one hand, if you say that during communism, many crimes were committed, someone from a communist family comes to you saying 'this is not true, people had jobs and social security'. On the other, when I say that there were some good things about communism then some right-winger comes and tells me 'you can't say that - there was no freedom!' $<$ laughing $>$ (Ondřej, 20, Prague, centre-left party).

\section{The role of school climate}

Another important finding is that not only formal education but also school climate was formative for interviewees' political values. For instance, some German participants described their school as focused on personal success, competitiveness and achievement which led to a lack of free time. Czech interviewees mentioned unjust treatment from teachers or schoolmates. In this respect, one interviewee described his experience from grammar school where he observed a conflict between a girl from an economically disadvantaged family and their classmates.

It [the difference] was obvious. She did not have branded clothes like my schoolmates had. ... She even did not have money for the textbooks and had to copy them... You know, some kind of elite was forming in the class and they ostracized her (Ondřej, 20, Prague, centre-left party, activist).

He also describes how they gossiped about her and taunted her. Finally, the situation deteriorated and she left the school. 'And I realized that I don't want to live in a world like that and to be judged by poverty and class membership' $<$ resolutely>. This experience had a strong impact on Ondřej's decision to enter 
the Czech Social Democratic Party because it has a left-wing rhetoric and should defend the poor'.

Another kind of pressure which Czech communication partners felt was the anti-communist or even anti-left-wing school climate. For individuals from left-wing families or with left-leaning opinions this situation was a source of stress despite the supposed apolitical school environment as one student active in the anarchist scene described:

The way civic education [was taught] was so conservative and anti-communist that [they said] that any model of democracy without capitalism was impossible. When a twelve-year-old is in this conservative school environment he does not have any chance to, or way of resisting (Kryštof, 26, Prague, anarchist and left-wing activist).

The negative perception of left-wing ideology is illustrated by one interviewee's experience: at school, he was confronted with the narrative of the unsuccessful leftist. In this narrative, to be rich meant just trying hard enough whereas poor people were simply not hardworking enough, and leftist ideology was connected with communism and the discourse of failure.

You know, this ethos of success. A leftist is a man who complains because he is not successful and wants a change. A rightist is a man who is successful and does not need any change (Ondřej, 20, Prague centre-left party, activist).

When I asked him if he was criticized for his political opinions by his teachers or peers he answered. 'Many times, actually since gymnasium. Most often it was something like "you are so clever so why are you leftist?",

While some left-leaning interviewees felt marginalized in the Czech Republic, their centre-right and conservative counterparts from West Germany had a similar experience ${ }^{11}$. They explained that right-wing ideology was not socially desirable among their classmates and they often felt overlooked, ignored or even ostracized by their peers. However, no differences in teachers' behaviour were reported. In this respect, experiences of interviewees from East Germany were not as polarizing and can be located somewhere between those of the Czech Republic and West Germany.

In the West German context, the dominant narrative positioned leftist politics as progressive while right-wing ideology was sometimes connected with extremism and Nazism. This situation also influenced the recruitment of communication partners which was more complicated in the case of identifying people from the centre-right and conservative end of the spectrum. They often refused interview requests and those who agreed were more reluctant in

\footnotetext{
11 This tendency was even stronger in the university but this is beyond the scope of the article. However, author pays attention to this issue in her further texts.
} 
speaking about their views on politics and pathways to activism than their leftwing counterparts. When I asked the reasons for this, they admitted peer pressure and ostracization. However, finally a similar political spectrum of communication partners was identified in both countries.

Results also show that former Czech and German students of gymnasiums ${ }^{12}$ evaluated school climates as 'tolerant' and 'without problems'. By contrast, interviewees who attended technical schools perceived these lessons and the school climate as 'very poor', 'demotivating' or even 'ignorant', as the following testimony illustrates. In this setting, politically interested students were teased and name-called by their peers ${ }^{13}$.

The environment in this Realschule ${ }^{14}$ was not that stimulating politically. We were like 14-15 year old guys playing videogames and didn't care about anything more sophisticated, like politics or society (Liam, 23, Mannheim, civil society organisation).

To conclude this subchapter; Czech and German interviewees experienced not only inspiration and encouragement at schools, but they also faced various obstacles and pressures. If they were able to resist these negative circumstances, this led to strengthening their self-confidence and citizenship competences which positively influenced their future paths towards activism. It motivated them to actively overcome obstacles and challenge authority if they felt in the right, as one interviewee's statement suggests: 'maybe that is why I am not afraid to argue with anyone when I feel that it's worth it' (Radek, 26, Prague, centre-left party member).

\section{Who benefits from civic education?}

I feel that everyone pressures me to have some political opinion which is kind of annoying for me because I think that actually I don't understand politics. For example, when I watch some discussions on TV, I simply don't understand many concepts and the things they are talking about. Recently, I was listening to some interviews and they were talking about the division of Chamber of Deputies and Senate, and I realised that I have heard about it so many times but the principle itself is still not clear to me (Karel, 21, Olomouc, no organisation).

This excerpt is from an interview with Karel, a student who summarised his attitude as 'politics is everywhere and it bothers me'. He comes from an apolitical family, does not discuss politics with his parents and peers and does

\footnotetext{
12 In the Czech and German context, it is a type of grammar school preparing students to attend university.

13 Nevertheless, research sample contained only limited number of students from technical schools. Therefore, any broader conclusions from this fact would not be drawn.

${ }^{14}$ German secondary school focuses on technical subjects and natural science.
} 
not belong to any voluntary association. In the case of students like Karel, civic education policy did not stimulate his interest, give him sufficient factual knowledge or enabled his understanding of basic political principles such as state power-structures.

So who benefits from civic education programmes? Qualitative analysis indicated that civic education is the most successful in combination with other factors such as an open school climate, politically-interested friends, membership in voluntary associations and particularly a supportive family background which can spark young people's interest.

In other words, positive attitudes to participation and a climate of political dialogue regardless of the particular ideology were necessary for development of a sense of self-efficacy. Having just motivating civic education lessons or coming from a politically interested family was mostly not enough to generate and maintain an interest in politics. However, interviewees having several of these characteristics in combination had a higher propensity for active citizenship. This is the experience of Theo, a Christian Democratic Party member who considers his family as the main source of his political interest.

This [civic education] was also pretty interesting. It was one of my better classes and it was good... My dad is really interested in politics... both my parents thought that it was always important to keep in touch with current world affairs and the news. I always asked them if this decision or that politician was good or bad and stuff like that... I would say they had big influence on me. Yeah, I am really glad that they could educate me before I actually took the class because I had learned something about the basics (Theo, 19, Jena, centre-right party member).

Moreover, German students who were previously interested in politics benefited more not only from lessons of civic education at school but as well as from materials and programmes organised by the BPB because: 'normally you don't access them. I think you really have to be interested already' (Liam, 23, Mannheim, no organisation). Communication partners were convinced that civic education is successful in deepening and stimulating political interest rather than sparking it off.

\section{Discussion and conclusion}

The analysis revealed different perceptions and evaluations of school-based civic education by Czech and German participants. German students were mostly satisfied with the quality of their civic education. They also positively evaluated the approach of their teachers who were perceived to be 'qualified', 'inspiring' and 'neutral' in the sense of opinion plurality and welcoming different points of view. 
This was manifested by not avoiding controversial subjects in discussions as well as by interrupting dialogue when it was obvious that a discussion had degraded into failing mutual persuasion. Interviewees stated that this setting of 'power-free dialogue' typified by mutual trust, understanding and the absence of pressure to feel, speak or do certain things in politics supported their selfconfidence as engaged citizens.

In contrast, Czech interviewees were more distrustful and pessimistic about civic education programmes. They agreed that their school system restricts the focus to factual information about politics in order to be neutral in the sense of an 'apolitical' school environment. Interviewees felt the avoidance of class discussions on controversial subjects, which was justified by a lack of time. In this 'discourse of avoidance' political discussions do not belong in schools partly because teachers were considered 'manipulative' and 'unqualified' by students.

Czech participants complained of ideological indoctrination and ostracization of left-wing attitudes despite the supposed 'apolitical' school environment. A similar pattern of isolation and marginalisation by their schoolmates described centre-right and conservative students from former West Germany. Nevertheless, this tendency was not particularly strong in the case of interviewees from the former East Germany which was probably caused by the post-communist context.

Based on the findings described above, I suggest the Czech Republic should be inspired by some aspects of the German education policy and dropping the pretence that Czech schools are 'apolitical' organisations and focusing instead on ideological balance, pro-democratic values and development of citizens' competences. I suggest supporting a climate of open discussion on current political issues in order to enhance students' critical and analytical skills.

In accordance with Niemi and Junn's (2005: 150) recommendations we should introduce more 'real politics' into the curricula and not 'avoid controversial issues'. In the Czech and East German context, this particularly means discussing modern history and tackling the communist legacy. Furthermore, in response to complaints about the over-full curriculum, an increase in the time and financial resources devoted to civic education in the Czech Republic would be appropriate. Moreover, the civic education curriculum should be redesigned in order to more effectively address the differences among gender, sexual, ethnic and religious minorities (Niemi Junn 2005).

I agree with results of Wood et al. (2018) from New Zealand that the best way to teach civic education is at the intersection of cognitive (knowledgebased) and affective (based on emotions, feelings and attitudes) competences (Wood et al. 2018). The stories of German interviewees, in accordance with 
findings of previous civic education studies (e.g. Kalmárová et al. 2017; Macháček 2002; Pasek et al. 2008; Quintelier - Hooghe 2012), prove that a combination of frontal teaching with practical experience (such as communitybased projects, meetings with local politicians, volunteering, fundraising) is the most efficient way to encourage political engagement and commitment.

Moreover, special efforts should be made to improve standards of civic teaching at Faculties of Education: for instance, an introductory course in civic education should be compulsory for all teachers in training. This change could encourage the teaching of civic education at secondary and grammar schools not as a specialized, separate subject but instead woven into other curricular in a more interdisciplinary fashion. Moreover, a platform for teachers of civic education to provide a space for exchange, networking and continuing professional development opportunities should be established (Preissová Krejčí et al. 2016).

Another core research finding was that not only formal education influenced the communication partners. Political profiling was seen also as a product of unintended consequences such as questioning school authority, the school climate and the ability to resist school pressure. In this regard, the presented analysis was proven in the Central European context by findings from numerous international studies such as (Campbell 2008; Castillo et al. 2015; Pasek et al. 2008). The results show that exposure to certain types of pressure strengthens a belief in one's own abilities and stimulates political activism.

In accordance with findings of Hooghe and Stolle (2005), Quintelier (2013), Wood et al. (2018), data shows that civic education lessons were particularly beneficial in combination with other factors including inspiring teachers, an open school climate, politically interested peers, membership in voluntary associations and a supportive family background ${ }^{15}$. Exposure to a wide range of pro-participatory political stimuli in family, school and among peers was crucial for creating self-confident, engaged citizens.

The research results have practical implications for education policy in both countries which should particularly focus on children from apolitical backgrounds. Moreover, special effort should be paid to civic education at technical schools in order to reduce inequalities in participation.

The presented insights into perceptions of civic education and school environment in two countries offer theoretical starting points for a transnational project across EU member states. This would facilitate the study of best practices in teaching democracy in the Central European context, or

\footnotetext{
15 Nevertheless, other results (e.g. García-Albacete 2014) show that civic education is particularly beneficial not only for students from very active family backgrounds but also for their counterparts from the least engaged environments. Surprisingly, according to the analysis of García-Albacete (2014) civic lessons were the least efficient for children from moderately interested families.
} 
comparisons of civic education programmes among Western and postcommunist democracies. Further academic research should also address all actors in education and give more space to the voices of students, their parents and teachers. Moreover, future research should focus in greater detail on the different types of secondary and grammar schools and pay attention to schools in socioeconomically disadvantaged regions.

Daniela Prokschová is a graduate student at the Department of Political Sociology at the Institute of Sociology of the Czech Academy of Sciences and a $P h D$ candidate in sociology at Charles University, Prague. She was a visiting researcher at the University of Cologne, the University of Mannheim and at the Friedrich-Schiller University of Jena. Her academic interests lie in the areas of youth political participation, political socialisation and civic education in the Central European context.

\section{REFERENCES}

ALMOND, G. A. - VERBA, S., 1963: Political Culture: Political Attitudes and Democracy in Five Nations. Princeton, New York: Princeton University Press.

BERNHAGEN, P. - MARSH, M., 2007: Voting and Protesting: Explaining Citizen Participation in Old and New European Democracies. Democratisation 14(1), 44-72.

CAMPBELL, D. E., 2008: The Civic Side of School Choice: An Empirical Analysis of Civic Education in Public and Private Schools. BYU Law Review 11(2), 487-523.

CASTILLO, J. C. - MIRANDA, D. - BONHOMME, M. - COX, C. - BASCOPÉ, M., 2015: Mitigating the Political Participation Gap from the School: The Roles of Civic Knowledge and Classroom Climate. Journal of Youth Studies 18(1), 16-35.

CRESWELL, J. W., 2013: Research Design: Qualitative, Quantitative, and Mixed Methods Approaches. Thousand Oaks, California: Sage Publications.

ČÁP, P. - MATĚJKA, O. - PROTIVÍNSKÝ, T., 2013: Občanské vzdělávání v ČR. Centrum občanského vzdělávání: Brno: Masarykova univerzita, Muni Press.

DALTON, R. J., 2008: The Good Citizen: How a Younger Generation is Reshaping American Politics. Washington, D.C.: CQ Press.

EHMANN, A., 2004: Learning from History - Online: A Project of Civic Education in Germany. Presented at the Workshop III: Competences in the Media and Information Society, Santiago de Compostela, Spain: Bundeszentrale für politische Bildung.

GAISER, W. - DE RIJKE, J. - SPANNRING, R., 2010: Youth and Political Participation Empirical Results for Germany within a European Context. Young 18(4), 427-450.

GARCIA-ALBACETE, G., 2014: Young People's Political Participation in Western Europe: Continuity or Generational Change? New York: Palgrave Macmillan.

GERRING, J., 2007: Case Study Research: Principles and Practices. Cambridge; New York: Cambridge University Press.

GUEST, G. - MACQUEEN, K. M. - NAMEY, E. E., 2012: Applied Thematic Analysis. Los Angeles: Sage Publication.

GYÁRFÁŠOVÁ, Z. - BÚTOROVÁ, O., 2010: Občianska participácia: trendy, problémy, súvislosti. Sociológia 42(5), 447-491. 
HOOGHE, M. - STOLLE, D., 2005: Youth Organisations within Political Parties: Political Recruitment and the Transformation of Party Systems. In: Forbrig, J. (ed.): Revisiting Youth Political Participation. Strasbourg: Council of Europe, pp. 43-51.

HOWARD, M. M., 2003: The Weakness of Civil Society in Post-Communist Europe, Cambridge: Cambridge University Press.

JENKINS, H. - ITO, M. - BOYD, D., 2015: Participatory Culture in a Networked Era: A Conversation on Youth, Learning, Commerce, and Politics. Hoboken, New Jersey: John Wiley \& Sons.

KALINA, O. - MATĚJKA, O. - BÖHLER, W. - ČÁP, P. - PROTIVÍNKÝ, T., 2013: Vyplatí se rozumět politice? Občanské vzdělávání. Klíč ke svobodě a prosperitě občanů. Praha: Konrad-Adenauer-Stiftung.

KALMÁROVÁ, V. - LÁŠTICOVÁ, B. - FINDOR, A. - HRUŠKA, M., 2017: Aké vzdelávacie faktory súvisia s postojmi slovenskỳch stredoškolákov a stredoškoláčok $\mathrm{k}$ menšinám? Bratislava: Štátna školská inšpekcia.

KATRŇÁK, T., 2004: Odsouzeni k manuální práci: vzdělanostní reprodukce v dělnické rodině. Praha: Sociologické nakladatelství (Slon).

KING, N. - HORROCKS, C., 2010: Interviews in Qualitative Research. Los Angeles: Sage.

KUDRNÁČ, A., 2017: Vliv klimatu školní třídy a jejího socioekonomického složení na občanské znalosti a postoj k volební účasti. Sociologický časopis/Czech Sociological Review 53 (2), 209-240.

KUHN, H.-W., 2013: Politische Bildung in Deutschland: Entwicklung-Stand-Perspektiven. Wiesbaden: Springer-Verlag.

KUSÁ, Z. - JUŠČÁKOVÁ, Z., 2017: Ready for Inclusive Education? Ethnographic and Survey Perspectives. Sociológia 49(3), 309-337.

LÁŠTICOVÁ, B. - HARGAŠOVÁ, L. - ANDRAŠČIKOVÁ, S. - DRÁL', P. - FINDOR, A., 2018: Perspektívy a limity vytvárania tolerantných medziskupinových postojov vo vyučovaní občianskej náuky na Slovensku. Studia Paedagogica 23(3), 69-90.

MACHÁČEK, L., 2002: Občianska participácia a výchova k európskemu občianstvu: Sociológia 34(5), 461-482.

MANNING, N. - EDWARDS, K., 2014: Does Civic Education for Young People Increase Political Participation? A Systematic Review. Educational Review 66(1), 22-45.

MANSFELDOVÁ, Z., 2013: The Czech Republic. In: Berglund, S., (ed.): The Handbook of Political Change in Eastern Europe. Northampton, MA: Edward Elgar Publishing, pp. 217-253.

MYCOCK, A. - TONGE, J., 2012: The Party Politics of Youth Citizenship and Democratic Engagement. Parliamentary Affairs 65(1), 138-161.

NIEMI, R. G. - JUNN, J., 2005: Civic Education: What Makes Students Learn. New Haven: Yale University Press.

NORRIS, P., 2002: Democratic Phoenix: Reinventing Political Activism. Cambridge; New York: Cambridge University Press.

PASEK, J. - FELDMAN, L. - ROMER, D. - JAMIESON, K. H., 2008: Schools as Incubators of Democratic Participation: Building Long-Term Political Efficacy with Civic Education. Applied Development Science 12(1), 26-37.

PREISSOVÁ KREJČÍ, A. - CICHÁ, M. - MALÁČOVÁ, J., 2016: Redukcionistické chápání multikulturní výchovy na českých školách. Studia Paedagogica 21(3), 63-79.

PROTIVÍNSKÝ, T. - DOKULILOVÁ, M., 2012: Občanské vzdělávání v kontextu českého školství. Brno: Masarykova univerzita.

Sociologia 52, 2020, No. 3 
QUINTELIER, E., 2013: The Effect of Political Socialisation Agents on Political Participation between the Ages of Sixteen and Twenty-One. In: Blanc, A., et al. (eds.): Growing into Politics: Contexts and Timing of Political Socialisation. Colchester: ECPR Press, pp. 139-160.

QUINTELIER, E. - HOOGHE, M., 2012: Political Attitudes and Political Participation: A Panel Study on Socialisation and Self-Selection Effects among Late Adolescents. International Political Science Review 33(1), 63-81.

REINHARDT, S., 2007: Werte-Bildung und Politische Bildung. In: Lange, D. Himmelmann, G. (eds.): Demokratiebewusstsein. Wiesbaden: VS Verlag für Sozialwissenschaften, pp. 134-144.

RUBIN, H. J. - RUBIN, I. S., 2011: Qualitative Interviewing: The Art of Hearing Data. Thousand Oaks, California: Sage Publications.

SANDBERG, J., 2005: How Do We Justify Knowledge Produced within Interpretive Approaches? Organisational Research Methods 8(1): 41-68.

SHEEHY, G., 2011: New Passages: Mapping Your Life across Time. New York: Ballantine Books.

SMÉKAL, V. - PROTIVÍNSKÝ, T. - JARUŠEK, P. - JANEČKOVÁ, P. - HOTOVÁ, F., 2010: Analýza občanského vzdělávání dospělých. Brno: Centrum občanského vzdělávání, Masarykova univerzita.

TONGE, J. - MYCOCK, A. - JEFFERY, B., 2012: Does Citizenship Education Make Young People Better-Engaged Citizens? Political Studies 60(3): 578-602.

VAN DETH, J. W., 2008: Einführung: Kinder als junge Staatsbürger. In: van Deth, J. W., et al. (eds.): Kinder und Politik: Politische Einstellungen von jungen Kindern im ersten Grundschuljahr. Wiesbaden: Springer-Verlag, pp. 9-27.

VERBA, S. - SCHLOZMAN, K. L. - BRADY, H. E., 1995: Voice and Equality: Civic Voluntarism in American Politics. Cambridge: Harvard University Press.

WESTLE, B., 2006: Politisches Interesse, subjektive politische Kompetenz und politisches Wissen - Eine Fallstudie mit Jugendlichen im Nürnberger Raum. In: Roller, E., et al. (eds.): Jugend und Politik: „Voll normal!““. Wiesbaden: Springer-Verlag, pp. 209-240.

WOOD, B. E. - TAYLOR, R. - ATKINS, R. - JOHNSTON, M., 2018: Pedagogies for Active Citizenship: Learning through Affective and Cognitive Domains for Deeper Democratic Engagement. Teaching and Teacher Education 75, 259-267.

ZÁPOTOČNÁ, O. - LUKŠÍK, I., 2010: Podiel školy na formovaní aktívneho občianstva. Sociológia 42(5): 492-515.

ZUKIN, C. - KEETER, S. - ANDOLINA, M. - JENKINS, K. - CARPINI, M. X. D., 2006: A New Engagement?: Political Participation, Civic Life, and the Changing American Citizen. Oxford; New York: Oxford University Press. 